\title{
Menakar Competitive Strategic Lembaga Perkreditan Desa di Bali
}

\author{
I Gusti Kade Pusdikardiana Alin ${ }^{(1)}$ \\ Ni Nyoman Sunariani ${ }^{(2)}$
}

\author{
PT. BPR Bank Kertiawan ${ }^{(1)}$ \\ Universitas Pendidikan Nasional ${ }^{(2)}$ \\ kadepusdikardiana@gmail.com ${ }^{(1)}$ \\ nyomansunariani@ymail.com ${ }^{(2)}$
}

\begin{abstract}
Lembaga Perkreditan Desa (LPD) spread over Bali are one of the financial services managed by Desa Pakraman. The LPD was established with the aim of encouraging the economic development of rural communities with targeted savings and effective capital distribution. Given the increasing number of competitors from other financial institutions, good governance and competitiveness strategies also need to be considered in its development. This study uses qualitative methods aimed at finding out how the competitiveness strategy in the LPD, by collecting data through interviews, observation and documentation. The location of the study was carried out in Negara Subdistrict with two LPDs chosen to represent this study, namely: LPD Desa Pakraman Lelateng (LPD with healthy conditions) and LPD Desa Pakraman Kaliakah Kangin (LPD with unhealthy conditions). Data were analyzed by SWOT analysis. Based on the results of the study it was found that, the LPD of Desa Pakraman Lelateng had a good image, trustworthiness, competent human resources, good business conditions, problem loans, utilization of technology and operational areas. The strategy that should be implemented is a focus strategy that is to provide services that are maximum for customer trust and an improved risk management strategy. Then in the LPD of Desa Pakraman Kaliakah Kangin, employee loyalty, a bad image of the organization, decreased trust, a decline in business, nonperforming loans and perarems that have not been resolved were found. The strategy that should be implemented is a strategy to optimize socialization to the community to restore trust in the institution.
\end{abstract}

Keyword: competitive strategic; SWOT analysis; Lembaga Perkreditan Desa 


\begin{abstract}
Lembaga Perkreditan Desa (LPD) yang tersebar di Bali merupakan salah satu jasa keuangan yang dikelola oleh Desa Pakraman. LPD didirikan dengan tujuan mendorong pembangunan ekonomi masyarakat desa dengan tabungan yang terarah dan penyaluran modal yang efektif. Mengingat semakin banyaknya kompetitor dari lembaga keuangan lainnya, tata kelola yang baik dan strategi daya saing juga perlu diperhatikan dalam pengembangannya. Penelitian ini menggunakan metode kualitatif bertujuan untuk mengetahui bagaimana strategi daya saing pada LPD, dengan pengumpulan data melalui wawancara, observasi dan dokumentasi. Lokasi penelitian dilakukan di Kecamatan Negara dengan dua LPD yang dipilih untuk mewakili penelitian ini yaitu: LPD Desa Pakraman Lelateng (LPD dengan kondisi sehat) dan LPD Desa Pakraman Kaliakah Kangin (LPD dengan kondisi kurang sehat). Data dianalisis dengan analisis SWOT. Berdasarkan hasil penelitian ditemukan bahwa, LPD Desa Pakraman Lelateng memiliki citra yang baik, kepercayaan, SDM yang kompeten, kondisi usaha yang baik, kredit bermasalah, pemanfaatan teknologi dan daerah operasional. Strategi yang sebaiknya diterapkan adalah strategi fokus yaitu memberikan pelayanan yang maksimal atas kepercayaan nasabah dan strategi manajemen resiko yang ditingkatkan. Kemudian pada LPD Desa Pakraman Kaliakah Kangin ditemukan loyalitas pegawai, citra lembaga yang buruk, kepercayaan yang menurun, penurunan usaha, kredit bermasalah serta perarem yang belum terseselsaikan. Strategi yang sebaiknya diterapkan adalah strategi mengoptimalkan sosialisasi kepada masyarakat untuk mengembalikan kepercayaan terhadap lembaga.
\end{abstract}

ABSTRAK

Kata kunci: competitive strategic; analisis SWOT; Lembaga Perkreditan Desa 


\section{PENDAHULUAN}

Indonesia dikenal sebagai negara agraris yang majemuk serta dapat digolongkan ke dalam masyarakat tradisional yang mempunyai karakteristik kehidupan ekonomi masyarakat didukung sepenuhnya dengan kondisi agraris dan budaya yang kental (Bali dan Darma, 2019). Guna mewujudkan pembangunan dan pemerataan ekonomi, pemerintah dapat memaksimalkan potensi daerah dengan memprioritaskan pembangunan daerah pedesaan untuk mendorong kemajuan pembangunan daerah maupun pembangunan nasional secara keseluruhan (Darma, 2018).

Untuk mencapai pembangunan di daerah yang optimal, pemerintah perlu memperhatikan karakteristik yang berbeda pada setiap daerah. Karakteristik tersebut dapat berupa sosial maupun budaya (Darma, 2019). Selain hal tersebut, terdapat hal lain yang harus juga diperhatikan yaitu, sektor pendanaan kepada masyarakat di daerah untuk dapat memajukan perekonomian mereka (Rusmahadewi dan Darma, 2018). Agar dapat menunjang dan memperlancar pembangunan perekonomian di daerah pedesaan khususnya serta untuk meningkatkan kehidupan desa, maka dipandang perlu membentuk suatu wadah yang dapat memberikan bantuan pendanaan atau pinjaman dan menampung segala keperluan masyarakat desa dibidang keuangan, salah satunya dengan keberadaan Lembaga Keuangan Mikro (LKM).

Pemberlakuan Undang-Undang Nomor 1 Tahun 2013 tentang Lembaga Keuangan Mikro (LKM), merupakan salah satu upaya pemerintah dalam menumbuhkembangkan perekonomian rakyat menjadi lebih tangguh, berdaya, dan mandiri yang berdampak terhadap peningkatan perekonomian daerah. Berbagai bentuk LKM yang ada saat ini seperti Lembaga Perkreditan Desa (LPD) di Bali merupakan potensi besar dalam meningkatkan akses permodalan bagi kegiatan ekonomi mikro yang merupakan basis perekonomian pada tingkat pedesaan.

Lembaga Perkreditan Desa (LPD) di Bali ini seutuhnya dikelola oleh masyarakat desa adat atau dikenal sebagai Desa Pakraman melalui orang-orang yang ditunjuk sebagai pengurus. LPD tidak hanya sekedar untuk pemenuhan sosial ekonomi tetapi juga bercorak kultural dan religius. Ini berkaitan erat dengan pemenuhan dan pelaksanaan kewajiban tidak hanya kewajiban pada alam semesta nyata (skala) tetapi juga kewajiban terhadap alam inmaterial (niskala) krama desa dalam wilayah Desa Pakraman tersebut. Lembaga keuangan komunitas ini bersifat sosial, ekonomi, dan religius, berbeda dengan orientasi dan filosofi lembaga keuangan mikro di daerah lain. 
Keberadaan LPD di Bali adalah melaui gagasan pembentukan LPD dicetuskan oleh Prof. Dr. Ida Bagus Mantra pada tahun 1980-an. Gagasan tersebut untuk pertama kalinya muncul dalam bentuk gagasan lembaga keuangan desa adat yang berbasis pada tradisi kelembagaan sosial yang telah ada di dalam tata kehidupan. Badan usaha ini yang sepenuhnya dimiliki dan dikelola oleh Desa Pakraman, merupakan sebagai lembaga bisnis yang dikelola dengan tujuan untuk memperoleh profit atau laba. Dari keuntungan yang diperoleh menurut Peraturan daerah Provinsi Bali Nomor 3 Tahun 2017 tentang Pembagian Keuntungan bahwa pembagian keuntungan bersih LPD pada akhir tahun pembukuan ditetapkan sebagai berikut: Cadangan Modal 60\%, Dana pembangunan dan pemberdayaan masyarakat desa $20 \%$, Jasa produksi 10\%, Dana pemberdayaan 10\% (paling banyak Rp. 300.000.000,-) dan Dana sosial 5\%.

Fungsi dan tujuan LPD adalah untuk mendorong pembangunan ekonomi masyarakat desa melalui kegiatan menghimpun dana dari Krama Desa, memberikan kesempatan berusaha bagi para masyarakat setempat, kemudian untuk memperluas kesempatan kerja yang ada di pedesaan, serta melancarkan lalu lintas uang, sekaligus menghapuskan keberadaan rentenir atau gadai gelap (Wibawa dan Darma, 2017). Untuk mencapai keberhasilan harus memiliki formula yang baik dalam mengelola sumber daya yang dimiliki. Tata kelola perusahaan yang baik merupakan pedoman atau bisa digunakan sebagai formula untuk menciptakan pedoman bagi pengelola perusahaan dalam mengelola manajemen perusahaan yang baik dengan memperhatikan kepentingan stakeholders (stakeholders dilingkungan LPD adalah krama desa, pemerintah, pengelola dan masyarakat) (Budiasni dan Darma, 2016).

Mengenai pengelolaan LPD, Perda Provinsi Bali No. 3 Tahun 2017 adalah perda terbaru tentang LPD. Perda ini baru disahkan dan disetujui oleh DPRD Provinsi Bali pada tanggal 27 April 2017. Ada beberapa perubahan yang dilakukan dalam perda ini. Ada tambahan pasal yang bertujuan untuk meningkatkan kinerja LPD serta untuk menjaga eksistensi LPD. Misalnya, di perda sebelumnya tidak ada pembatasan umur pengurus LPD, di Perda sekarang sudah ada pasal yang mengatur tentang itu. Pengurus LPD yang sudah berusia 60 tahun sudah harus pensiun. Pasal lain juga mengatur tentang audit LPD. Kalau sebelumnya tidak ada pasal yang mewajibkan LPD diaudit, tapi sekarang sudah diatur tentang ketentuan itu. Terkait lembaga penjaminan simpanan nasabah LPD juga sekarang sudah diatur.

Selain dengan tata kelola yang baik, dalam pengembangannya perlu diperhatikan juga mengenai daya saing LPD juga harus selalu ditingkatkan mengingat semakin banyaknya kompetitor dari lembaga keuangan atau pembiayaan lainnya seperti koperasi, perusahaan 
pembiayaan, pegadaian dan lainnya yang semakin mudah dalam memberikan pendanaan pada masyarakat dan pelaku usaha mikro (Darma, 2012).

Penelitian pemberdayaan LPD dilakukan oleh Wiagustini (2014) yang memaparkan penentu keberhasilan LPD sebagai sumber pendanaan UMKM di Kabupaten Gianyar terdiri dari faktor strategis internal dan faktor strategis eksternal. Faktor strategis internal akan menjadi kekuatan atau kelemahan. Faktor strategis internal yang teridentifikasi: jumlah kredit yang disalurkan, jumah dana pihak ketiga, tingkat bunga kredit LPD, kebijakan penyaluran kredit, kualitas pelayanan, dukungan promosi, kualitas dan kompetensi sumber daya manusia, loyalitas SDM, budaya organisasi, komitmen dan kompetensi pengurus, dukungan peralatan administrasi dan komunikasi serta sistem pengendalian akuntansi Faktor strategis eksternal merupakan peluang atau ancaman bagi LPD.

Faktor Strategis eksternal teridentifikasi: laju pertumbuhan ekonomi, suku bunga pinjaman, dukungan permodalan dari pemerintah, inflasi, sikap masyarakat, budaya/ adat istiadat masyarakat setempat, perkembangan jumlah UMKM, perkembangan jumlah lembaga keuangan, kebijakan peraturan pemerintah, serta perkembangan teknologi informasi. Kemudian posisi strategis LPD Kabupaten Gianyar diperoleh memiliki daya saing yang kuat sehingga strategi yang diterapkan adalah strategi bertumbuh dan membangun. Mandala (2016) mengemukakan mengenai perkembangan, tantangan dan perspektif kebijakan pengembangan LPD, bahwa perkembangan dan kondisi LPD di Bali saat ini berkembang pesat. Hal tersebut terlihat dari aset yang dihimpun telah mencapai jumlah yang signifikan. Namun tidak dapat dipungkiri bahwa masih banyak LPD yang menghadapi permasalahan baik dari sisi teknis pengelolaan keuangan maupun dari sisi SDM.

Dalam mengatasi hal tersebut diperlukan suatu pembinaan dan pengawasan secara bertahap oleh pemerintah daerah melalui dinas-dinas yang terkait. Hal ini sangat penting mengingat masyarakat adat dan desa adat sudah sangat merasakan peranan LPD sebagai lembaga intermediasi dalam kegiatan ekonomi masyarakat. LPD mesti membenahi istitusinya dalam segala aspek mulai dari pemasaran, keuangan, kepersonaliaan dan juga pembenahan di dalam organisasinya. Agar mempunyai daya saing yang baik maka perlu dirumuskan stategi daya saing atau manajemen strategi daya saing untuk pengembangan atau keberlajutan usaha dari lembaga tersebut. Sebelum merumuskan strategi daya saing maka diperlukan analisis yang baik secara internal maupun eksternal, sehingga dapat diketahui kondisi dalam perusahaan dan kondisi luar perusahaan. Untuk bisa mengetahui kekuatan serta kelemahan dari dalam dan luar maka diperlukanlah analis faktor internal dan faktor internal. 
Kecamatan Negara memiliki Lembaga Perkreditan Desa sejumlah sepuluh lembaga. Dengan aset yang dimiliki adalah Rp. 122,684,635,000.00. dari sepuluh lembaga tersebut, terdapat Sembilan LPD yang di kategorikan sehat sedangkan terdapat satu LPD yang dikategorikan kurang sehat, dengan data pada tabel sebagai berikut:

Tabel 1.1

Laporan Aset dan kondisi LPD Kecamatan Negara Per Desember 2018

\begin{tabular}{|c|l|r|l|c|}
\hline No & \multicolumn{1}{|c|}{ Nama LPD } & Aset & \multicolumn{1}{|c|}{ Kondisi } & SK. Gub \\
\hline 1 & Lelateng & 35.190 .355 .000 & Sehat & 151 Th. 1990 \\
\hline 2 & Baler Bale Agung & 18.484 .486 .000 & Sehat & 58 Th. 1991 \\
\hline 3 & Berambang & 24.066 .574 .000 & Sehat & 268 Th. 1989 \\
\hline 4 & Kaliakah Kauh & 2.749 .010 .000 & Sehat & 739 Th.1992 \\
\hline 5 & Puseh Agung & 400.144 .000 & Sehat & 51 Th.1989 \\
\hline 6 & Baluk & 20.798 .147 .000 & Sehat & 151 Th.1990 \\
\hline 7 & Tegal Badeng Kauh & 4.569 .401 .000 & Sehat & 739 Th.1992 \\
\hline 8 & Tegal Badeng Kangin & 3.868 .025 .000 & Sehat & 58 Th.1991 \\
\hline 9 & Banyubiru & 12.186 .754 .000 & Sehat & 17 Th.1991 \\
\hline 10 & Kaliakah Kangin & 371.739 .000 & Kurang Sehat & 739 Th.1992 \\
\hline & Total & 122.684 .635 .000 & & \\
\hline
\end{tabular}

Berdasarkan pemaparan dan data pada tabel di atas tersebut peneliti tertarik untuk melakukan penelitian mengenai rumusan strategi daya saing LPD, karena dilihat dari data di atas ditemukan fenomena dimana terdapat satu LPD yang dinyatakan kurang sehat dari sepuluh LPD yang ada di kecamatan Negara, LPD yang dikategorikan kurang sehat yaitu LPD Desa Pakraman Kaliakah Kangin. Berdasarkan fenomena tersebut, peneliti bermaksud untuk melakukan penelitian pada LPD Desa Pakraman Kaliakah Kangin dan sebagai perbandingan dipilih LPD Desa Pakraman Lelatang sebagai LPD yang mewakili LPD yang dikategorikan sehat. Oleh karena itu peneliti tertarik untuk mengetahui kondisi internal dan eksternal perusahaan tersebut sehingga bisa dirumuskan strategi bersaing yang tepat. 
Strategi merupakan bakal tindakan yang menuntun keputusan manajemen puncak dan sumber daya perusahaan yang banyak merealisasikannya. Di samping itu, strategi juga mempengaruhi kehidupan organisasi dalam jangka panjang, paling tidak selama lima tahun. Strategi mempunyai konsekuensi multifungsional atau multidivisional dan dalam perumusannya perlu mempertimbangkan faktor-faktor internal maupun eksternal yang dihadapi perusahaan (Rachmat: 2014; Kanten dan Darma, 2017). Manajemen strategi merupakan serangkaian keputusan dan tindakan manajerial yang menentukan kinerja perusahaan jangka panjang yang meliputi pengamatan lingkungan, perumusan strategi, implementasi strategi dan evaluasi serta pengendalian (Hunger dan Wheelen:1998; Darma, 2004). Dalam manajemen strategi, perusahaan dapat memahami kekuatan bersaing dan mengembangkan keunggulan kompetitif berkelanjutan secara sistematis dan konsisten. Manajemen strategik di katakan efektif apabila memberi tahu seluruh karyawan mengenai sasaran bisnis, arah bisnis, kemajuan ke arah pencapaian sasaran dan pelanggan, pesaing dan rencana produk. Manajemen strategik umumnya berorientasi pada lingkungan yang dapat memberikan hasil yang menguntungkan (Assauri: 2016). Sehingga apabila manajemen strategik telah berhasil diterapkan dengan baik maka perusahaan akan mempunyai keunggulan yang lebih dari kompetitornya.

LPD pertama kali diprakarsai oleh Gubernur Bali saat itu, Prof. Ida Bagus Mantra, setelah pada tahun 1985 beliau berkunjung ke Sumatra Barat. Di sana ada Lembaga Keuangan milik adat yang berkembang dengan baik yang diberi nama "Lumbung Pitih Nagari”. Beberapa bulan kemudian beliau mengikuti seminar di Semarang mengenai Lembaga Keuangan Desa (LKD) atau Badan Kredit Desa (BKD). Dari kedua peristiwa itulah beliau menilai bahwa Bali memiliki potensi dan kesempatan untuk membentuk suatu Lembaga Keuangan yang dikelola oleh lembaga adat/Pakraman seperti yang ada di Sumatra Barat. Pada awalnya LPD dibuat satu di tiap kabupaten. Setelah melihat hasilnya yang berkembang dengan pesat maka akhirnya dibuatlah Peraturan Daerah Tingkat I Bali Nomor 2 Tahun 1988 tentang Lembaga Perkreditan Desa. Kemudian untuk mengontrol manajemen dan kinerja LPD, maka pada tahun 1997 ditetapkan Peraturan Daerah Tingkat I Bali Nomor 199 Tahun 1997 tentang Pembentukan Susunan Keanggotaan Badan Pembina Lembaga Perkreditan Desa Propinsi Daerah Tingkat I Bali. Badan Pembina LPD ini selain melakukan pembinaan dan pengawasan juga mengevaluasi hasil laporan tahunan tiap LPD sebagai acuan pembinaan selanjutnya. Menurut Peraturan Daerah Provinsi Bali No. 8 Tahun 2002, LPD adalah usaha keuangan milik desa yang melaksanakan kegiatan usaha di lingkungan desa dan untuk krama desa. LPD Merupakan 
lembaga keuangan milik desa pakraman yang telah berkembang dan memberikan manfaat sosial, ekonomi, budaya pada anggotanya. Dengan demikian, LPD harus dibina dan ditingkatkan kinerjanya untuk pencapaian peningkatan taraf hidup masyarakat pedesaan. Perda Provinsi Bali No. 3 Tahun 2017 adalah perda terbaru tentang LPD. Perda ini baru disahkan dan disetujui oleh DPRD Provinsi Bali pada tanggal 27 April 2017.

Analisis SWOT adalah identifikasi berbagai faktor untuk merumuskan strategi perusahaan. Analisis ini didasarkan pada logika yang dapat memaksimalkan kekuatan (strengts) dan peluang (opportunities), namun secara bersamaan dapat meminimalkan kelemahan (weakness) dan ancaman (threats). Keputusan strategis perusahaan perlu pertimbangan faktor internal yang mencakup kekuatan dan kelemahan maupun faktor eksternal yang mencakup peluang dan ancaman. Oleh karena itu perlu adanya pertimbanganpertimbangan penting untuk analisis SWOT (Freddy Rangkuti 2013:18).

Tabel 1: Matrik SWOT

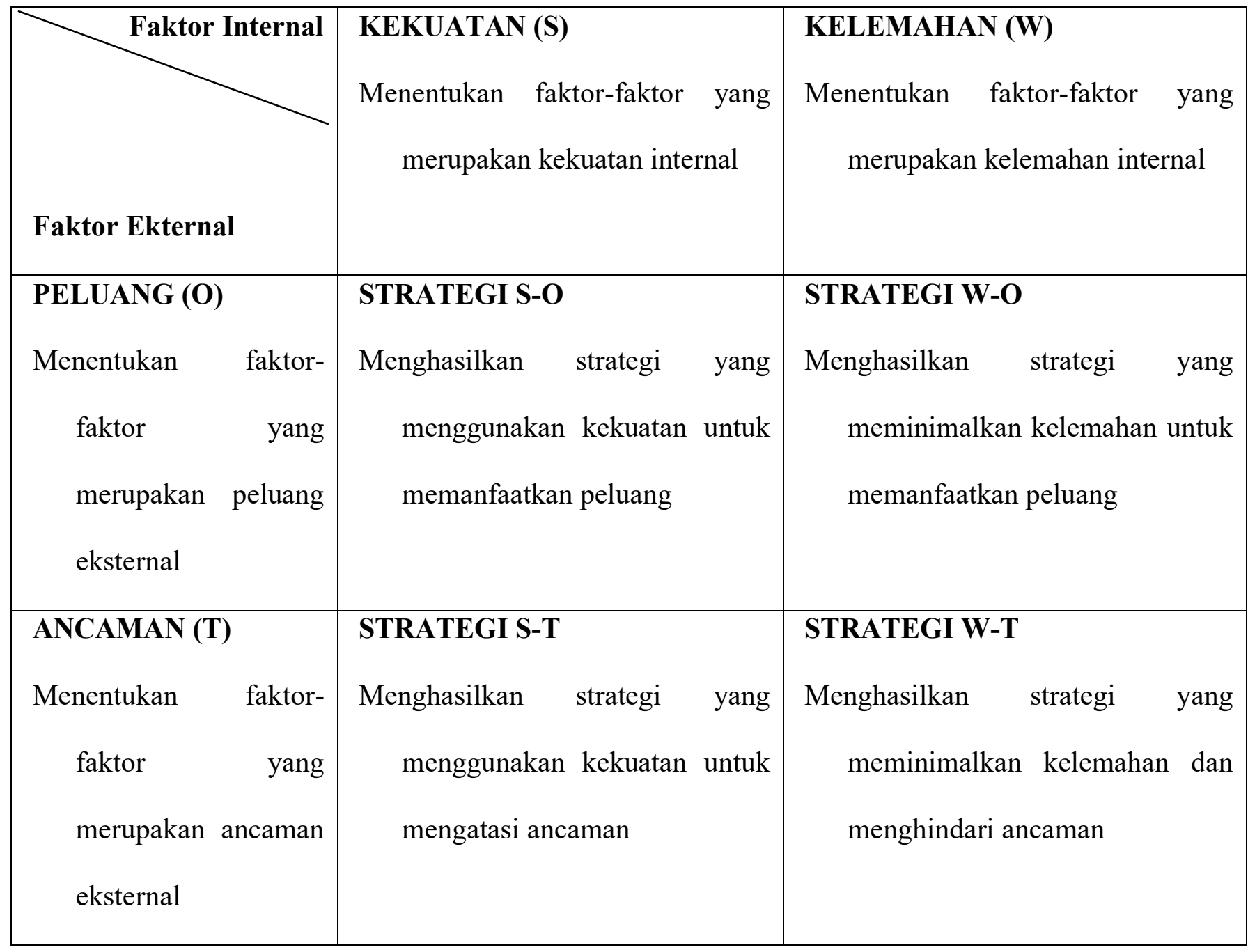

Sumber : Rangkuti (2013) 
Kerangka konsep merupakan model konseptual yang berkaitan dengan bagaimana seorang peneliti menyusun teori atau menghubungkan secara logis beberapa faktor yang dianggap penting untuk masalah (Hidayat, 2009). Kerangka konsep dalam penelitian ini dapat dilihat dalam gambar berikut ini.

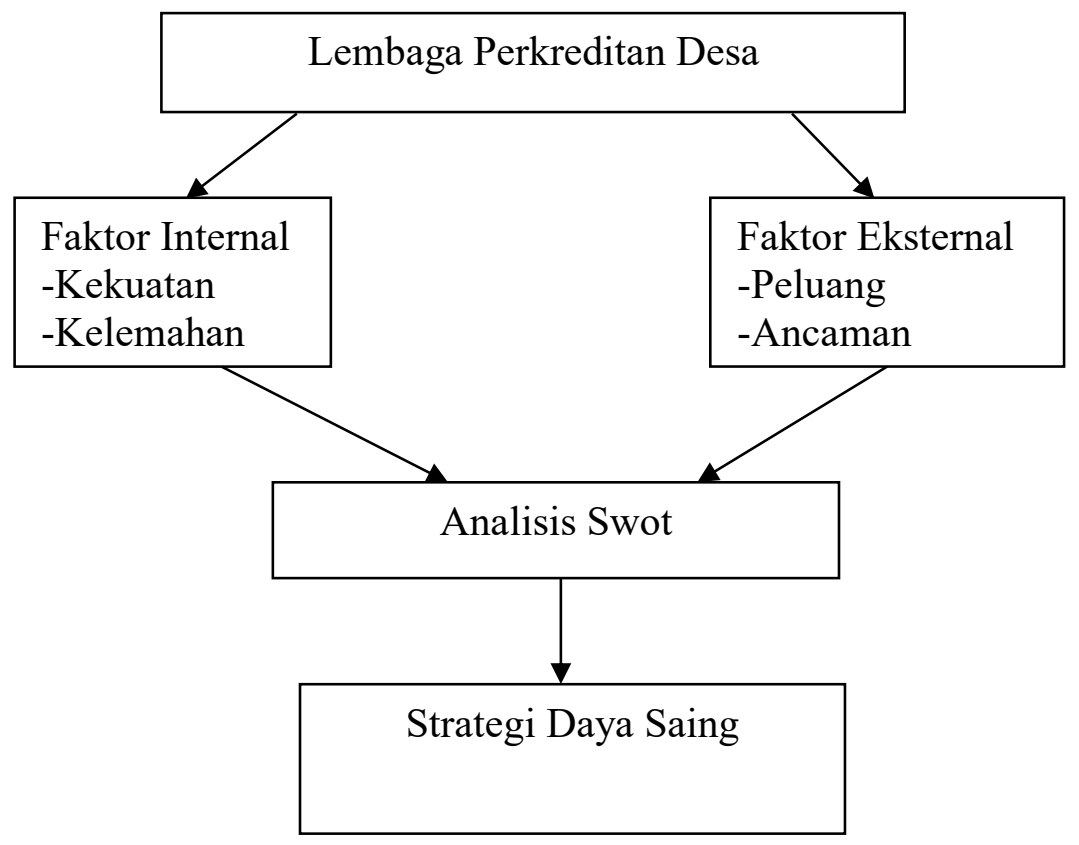

\section{METODE PENELITIAN}

Dalam penelitian ini, desain penelitian yang digunakan oleh peneliti adalah metode kualitatif yang bersifat studi kasus. Peneliti mengambil tempat peneitian di LPD Desa Pakraman Lelateng dan LPD Desa Pakraman Kaliakah Kangin. Sumber data primer dari penelitian ini yaitu data yang diperoleh dari kepala LPD dan pengawas. Penentuan Informan pada penelitian ini dilakukan dengan teknik purposive sampling dimana pemilihan informan dipilih secara sengaja berdasarkan kriteria yang telah ditentukan dan ditetapkan berdasarkan tujuan penelitian. Uji keabsahaan data pada penelitian adalah dengan mengunakan triangulasi metode dan sumber.

\section{PEMBAHASAN}

Faktor Internal LPD Desa Pakraman Lelateng

Faktor internal dalam sebuat perusahaan terdiri atas kelemahan dan keunggulan. Melalui penelitian yang dilakukan di LPD Desa Pakraman Lelateng baik secara wawancara mendalam 
maupun observasi didapatkan keunggulan dari LPD Desa Pakraman Lelateng adalah sebagai berikut:

a. Citra atau image berkaitan dengan reputasi sebuah merek atau perusahaan. Citra adalah persepsi konsumen tentang kualitas yang berkaitan dengan merek atau perusahaan. Menurut Simamora (2007) menyatakan citra adalah persepsi yang relatif konsisten dalam jangka panjang (enduring perception). Jadi tidak mudah untuk membentuk citra, sehingga bila terbentuk akan sulit untuk mengubahnya. Citra yang dibentuk harus jelas dan memiliki keunggulan bila dibandingkan dengan pesaingnya. Seperti halnya dengan LPD Desa Pakraman Lelateng, telah dikenal memiliki citra yang baik bagi Krama Desa Pakraman Lelateng. LPD ini mendapat kepercayaan yang baik dari Krama Desa Pakraman Lelateng bahkan dari luar desa sekalipun sehingga dalam penghimpunan dan penyaluran dana LPD Desa Pakraman Lelateng hampir tidak mengalami kesulitan.

b. SDM merupakan unsur strategis yang tidak bisa diabaikan dalam organisasi. Perubahan lingkungan bisnis serta kemajuan informasi dan teknologi, menjadi tantangan utama bagi SDM. Menurut Hasibuan (2014 : 244), Sumber daya manusia adalah Kemampuan terpadu dari daya pikir dan daya fisik yang dimiliki individu. Perilaku dan sifatnya ditentukan oleh keturunan dan lingkungannya, sedangkan prestasi kerjanya dimotivasi oleh keinginan untuk memenuhi kepuasannya. sumber daya manusia yang dimiliki oleh LPD Desa Pakraman Lelateng telah memiliki kompetensi sesuai dengan bidang kerjanya masing-masing sehingga tidak mengalami kesulitan dalam menyelesaikan tugas dan tanggung jawabnya masingmasing. Dalam hal pengembangan dan peningkatan kualitas sumber daya manusia, LPD Desa Pakraman Lelateng telah memberikan dan mengikut sertakan sertifikasi dan pelatihan kepada seluruh staf.

c. LPD Desa Pakraman Lelateng secara umum memiliki kondisi usaha yang baik. LPD Desa Pakraman Lelateng meningkat pada tiap tahunnya, baik dari segi aset, simpanan, penyaluran kredit, pendapatan, biaya serta labanya melebihi target yang ditetapkan pada tahun sebelumnya. Ini mengindikasikan bahwa usaha yang dikelola oleh pengurus lembaga ini dilakukan dengan baik. Berikut dapat dilihat pada tabel: 
Tabel.2

Volume Pertumbuhan LPD Desa Pakraman Lelatang 2016 s/d 2018

(dalam ribuan)

\begin{tabular}{|l|c|c|c|c|}
\hline & 2016 & 2017 & 2018 & $\begin{array}{c}\text { Pertumbuhan } \\
\text { (\%) }\end{array}$ \\
\hline Aset & $26,291,150$ & $30,135,630$ & $35,190,355$ & 15.69 \\
\hline Simpanan & $20,395,802$ & $22,061,950$ & $25,132,511$ & 11.04 \\
\hline Kredit & $15,836,967$ & $18,420,221$ & $18,996,316$ & 9.71 \\
\hline Pendapatan & $3,598,439$ & $4,123,993$ & $4,400,641$ & 10.65 \\
\hline Biaya & $2,497,893$ & $2,909,845$ & $3,036,472$ & 10.42 \\
\hline Laba & $1,100,546$ & $1,214,128$ & $1,364,169$ & 11.33 \\
\hline
\end{tabular}

d. Kepercayaan konsumen dinyatakan sebagai komponen penting untuk menjaga hubungan yang berkelanjutan diantara semua pihak yang terlibat dalam bisnis (Zur et al; 2012). Dengan kepercayaan yang terbangun dari berbagai pihak yang terlibat dalam bisnis memungkinkan bisnis bisa terjalin dengan insentif. Kepercayaan Krama Desa Pakraman Lelateng yang tinggi, dapat dilihat dari partisipasi krama dalam memanfaatkan keberadaan LPD dengan menabung maupun meminjam dana di LPD Desa Pakraman Lelateng yang meningkat setiap tahunnya.

1. Kemudian berdasarkan penelitian yang dilakukan melalui wawancara mendalam maka dapat kelemahan atau weakness dari LPD Desa Pakraman Lelateng adalah sebagai berikut:

a. Dalam perjalanannya, suatu usaha lembaga keuangan tidak lepas dari adanya suatu kredit bermasalah. Begitu pula pada LPD Desa Pakraman Lelateng, yang juga ditemukan adanya kredit bermasalah atau non performing loan, ditemukan bahwa kredit bermasalah pada lembaga ini mengalami peningkatan dalam 3 (tiga) tahun terakhir yaitu 3.17\% pada 2016, 5,97\% pada 2017 dan 7,70\% pada 2019. Peningkatan ini dapat disebabkan oleh melemahnya dari usaha debitur yang mengakibatkan terganggunya pengembalian kredit serta dalam beberapa kasus ditemukan kelemahan dalam analisa kredit tersebut.

b. Dalam pemanfaatan teknologi informasi, LPD yang merupakan unit usaha yang berfungsi sebagai wadah kekayaan milik Desa Pakraman dengan pengelolaan LPD yang menjadi semakin kompleks. Mulai dari volume transaksi yang semakin besar, 
komplesitas pengolahan transaksi yang semakin tinggi serta adanya tuntutan menyediakan laporan keuangan yang lebih cepat dan akurat menyebabkan LPD perlu memanfaatkan teknologi informasi yang lebih canggih. Berdasarkan penelitian yang dilakukan Arifianto (2012) mengenai Perancang dan implementasi aplikasi pemesanan makanan dan minuman berbasis client service dengan platform android pada Waroeng Steak and Shake ini menyimpulkan penggunaan teknologi android pada rumah makan akan memudahkan proses pemesanan. LPD Desa Pakraman Lelateng ditemukan bahwa proses pencatatan masih menggunakan pencatatan secara manual dengan mengunakan kertas. Hal ini dirasa kurang efisien karena selain petugas harus datang ke nasabah baik itu dirumah ataupun di tempat usahanya untuk mencatat transaksi. Setelah petugas sampai kantor, petugas ini harus kembali merekap transaksi yang dilakukan pada hari tersebut ke dalam komputer dan proses ini membutuhkan waktu yang lama karena jumlah nasabah yang banyak. Oleh karena itu diperlukan suatu sistem yang terintegrasi untuk lebih efisien dalam pengerjaan maupun dalam pelayanan ke nasabah

c. LPD adalah lembaga keuangan milik Desa Pakraman yang berkedudukan di wewidangan desa pakraman, kemudian pada pasal 9 dinyatakan bahwa LPD melaksanakan kegiatan operasional usaha di lingkungan desa dan untuk krama desa. Berdasarkan hal tersebut, operasional LPD terbatas pada wilayah atau wewidangan desa pakraman.

\section{Faktor Eksternal LPD Desa Pakraman Lelateng}

a. Peluang adalah berbagai hal dan situasi yang menguntungkan bagi suatu perusahaan, serta kecenderungan-kecenderungan yang merupakan salah satu sumber peluang (Freddy Rangkuti, 2013). Desa Pakraman Lelateng merupakan daerah yang sedang berkembang, sebagai pusat pemukiman, perdagangan, industri dan pertanian. Pangsa pasar yang masih terbuka lebar dari sisi usaha-usaha kecil yang banyak ditambah lagi dengan adanya pasar desa sebagai tempat perputaran perekonomian di desa pakraman Lelateng ini Kemudian penggalian dana masih dapat ditingkatkan mengingat banyaknya usaha-usaha produktif yang tumbuh dan berkembang di wilayah desa pakraman Lelateng. Kepercayaan yang tinggi oleh krama desa terhadap LPD ini merupakan peluang yang baik dalam mengembangkan terus usahanya. Peluang lainnya adalah, saat ini oleh kepala LPD 
serta Bendesa juga sedang mendiskusikan mengenai rencana untuk membuat dan mengembangkan kelompok-kelompok usaha di tiap banjar yang akan dibiayai oleh LPD dengan bunga pengembalian yang lebih rendah. Ini bertujuan untuk mengembangkan potensi serta kreatifitas krama untuk mampu memiliki penghasilan yang lebih serta megembangkan perekonomian desa.

b. Masuknya pesaing baru, lambatnya pertumbuhan pasar, meningkatnya kekuatan tawar-menawar pembeli atau pemasok penting, perubahan tekhnologi, serta peraturan baru atau yang direvisi dapat menjadi ancaman bagi keberhasilan perusahaan (Freddy Rangkuti, 2013). Ketatnya persaingan baik dari bank umum, BPR, koperasi serta lembaga pembiayaan lainnya yang telah masuk sampai ketingkat pedesaan. Dimana masing lembaga keuangan berlomba-lomba untuk menarik nasabah dengan berbagai cara misalnya menawarkan bunga yang lebih kompetitif. Selain itu pula dengan menggunakan pendekatan yang lebih efisien terhadap nasabah.

\section{Analisis SWOT LPD Desa Pakraman Lelateng}

\begin{tabular}{|c|c|c|}
\hline$\underbrace{\text { Faktor Internal }}_{\text {Faktor Eksternal }}$ & $\begin{array}{l}\text { KEKUATAN (S) } \\
\text { - } \quad \text { Citra lembaga yang baik } \\
\text { - } \quad \text { Kepercayaan dan kedekatan } \\
\text { personal krama desa terhadap } \\
\text { LPD } \\
\text { - } \\
\text { - }\end{array}$ & $\begin{array}{l}\text { KELEMAHAN }(\mathbf{W}) \\
\text { - } \\
\text { - } \\
\text { - } \\
\text { Pemanfit Bermasalah teknologi } \\
\quad \text { terbatas }\end{array}$ \\
\hline $\begin{array}{l}\text { PELUANG (O) } \\
\text { Prospek pembiayaan } \\
\text { masih terbuka untuk } \\
\text { pelaku usaha, } \\
\text { penggalian dana } \\
\text { masih dapat } \\
\text { ditingkatkan } \\
\text { mengingat wilayah }\end{array}$ & $\begin{array}{l}\text { STRATEGI S-O } \\
\text { - Memaksimalkan jaringan } \\
\text { dengan sosialisasi dan } \\
\text { menggunakan media promosi } \\
\text { yang lebih agresif } \\
\text { - Mengembangkan unit-unit } \\
\text { kelompok usaha kecil } \\
\text { - Memanfaatkan besarnya } \\
\text { kepercayaan tersebut untuk } \\
\text { mengelola perkonomian desa } \\
\text { secara mandiri sehingga LPD } \\
\text { dapat semakin berkembang yang } \\
\text { didorong oleh perkembangan } \\
\text { perekonomian desa }\end{array}$ & 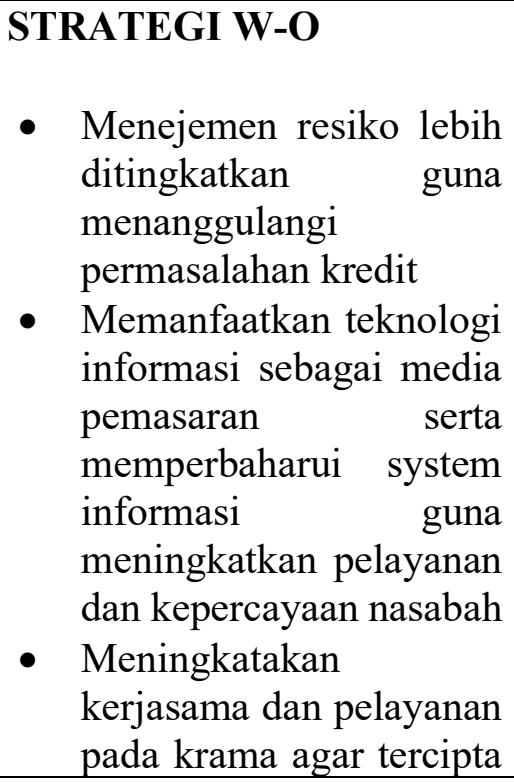 \\
\hline
\end{tabular}




\begin{tabular}{|c|c|c|}
\hline $\begin{array}{l}\text { Desa Lelateng } \\
\text { merupakan daerah } \\
\text { berkembang }\end{array}$ & & $\begin{array}{l}\text { rasa percaya memiliki } \\
\text { terhadap LPD }\end{array}$ \\
\hline $\begin{array}{l}\text { ANCAMAN (T) } \\
\text { Persaingan antar } \\
\text { sesama lembaga } \\
\text { keuangan }\end{array}$ & $\begin{array}{l}\text { STRATEGI S-T } \\
\text { - LPD telah memiliki kepercayaan } \\
\text { yang besar karena kedekatan } \\
\text { secara secara adat. Fokus pada } \\
\text { pelayanan yang baik untuk } \\
\text { kepentingan perekonomian } \\
\text { krama agar tetap dipercaya } \\
\text { karena sekalipun LPD tidak } \\
\text { memiliki layanan mobile } \\
\text { banking, pada dasarnya dapat } \\
\text { digantikan dengan pelayanan } \\
\text { yang lebih baik dan professional. } \\
\text { Lebih banyak melakukan } \\
\text { sosialisasi dan menjaga nama } \\
\text { baik LPD }\end{array}$ & $\begin{array}{l}\text { STRATEGI W-T } \\
\text { Mengoptimalkan pelayanan, } \\
\text { sosialisasi dan pembinaan } \\
\text { kepada nasabah guna } \\
\text { mempromosikan LPD serta } \\
\text { untuk menyelesaikan kredit } \\
\text { bermasalah }\end{array}$ \\
\hline
\end{tabular}

4. Faktor Internal LPD Desa Pakraman Kaliakah Kangin

a. Miguel Pina E (2002) yang mengatakan bahwa sikap loyalitas yang dimiliki karyawan dapat diketahui dengan adanya pengakuan bahwa bekerja untuk organisasi merupakan pilihan terbaik mereka. LPD Desa Pakraman Kaliakah Kangin, sumber daya manusia yang dimiliki oleh LPD Desa Pakraman Kaliakah Kangin yaitu berupa loyalitas karyawan di LPD Desa Pakraman Kaliakah Kangin cukup tinggi serta semangat kerja mereka yang tinggi dalam melayani nasabah dan rasa berkeinginan memajukan LPD yang tinggi. Rasa kekeluargaan dirasakan membuat karyawan loyal pada lembaga ini. Loyalitas dalam diri karyawan menjadi keuntungan bagi perusahaan karena karyawan menjadi peduli terhadap perusahaan.

b. Citra perusahaan didefinisikan sebagai persepsi tentang sebuah organisasi yang terefleksi dalam ingatan pelanggan. Menurut Simamora (2007) menyatakan citra adalah persepsi yang relatif konsisten dalam jangka panjang (enduring perception). JMenurut penelitian mengenai pentingnya sebuah citra perusahaan oleh Ni Putu Dharma Diyanthini (2014) dengan judul penelitian "Pengaruh Citra Perusahaan, Promosi Penjualan dan Kualitas Pelayanan Terhadap Kepuasan Nasabah Pada 
LPD Desa Pakraman Panjer", disimpulkan bahwa sebuah brand akan menjadi pertimbangan oleh pelanggan dalam menentukan keputusan untuk membeli produk atau tidak. Jadi jika perusahaan tersebut mempunyai reputasi yang baik dan brandnya cukup dikenal maka peluang untuk dipilihnya produk/jasa dari perusahaan tersebut cukup besar. Berdasarkan penelitian yang dilakukan peneliti diketahui bahwa LPD Desa Pakraman Kaliakah Kangin ini memiliki brand image yang kurang baik sehingga kepercayaan masyarakat terhadap LPD Kaliakah Kangin pun kurang baik. Citra yang kurang baik ini disebabkan oleh penyimpangan dari pengurus LPD sebelumnya, yang kemudian sampai saat ini mengakibatkan sulitnya mengembalikan kepercayaan dan partisipasi krama untuk mendapatkan pendanaan d Kepercayaan pelanggan merupakan evaluasi purna jual dimana alternatif yang diplih sekurang-kurangnya sama atau melebihi harapan pelanggan. Mayer et al (1995) mengemukakan faktor yang membentuk kepercayaan seseorang terhadap yang lain ada 3 (tiga) yaitu: kemampuan (ability), kebaikan hati (benevolence), dan integritas (integrity). Organisasi yang berorientasi pelanggan harus mempelajari apa yang dihargai konsumen dan menyiapkan suatu tawaran yang melebihi harapan mereka.

c. Berdasarkan penelitian yang dilakukan peneliti ditemukan bahwa kepercayaan krama desa pakraman kaliakah kangin yang rendah terhadap LPD. Kepercayaan yang rendah mengakibatkan partisipasi masyarakat untuk ke LPD juga rendah. Hal ini disebabkan oleh terjadinya penyimpangan oleh pengurus LPD di masa sebelumnya. Krama yang merasa dirugikan oleh penyimpangan tersebut masih belum bisa kembali mempercayai LPD walaupun kepengurusan LPD saat ini sudah digantikan oleh pengurus yang baru.an juga menyalurkannya.

d. Berkaitan dengan strategi daya saing Lembaga Perkreditan Desa, ditemukan bahwa LPD Desa Pakraman Lelateng secara umum memiliki kondisi usaha yang menurun dalam tiga tahun terakhir. 
Tabel 3

Volume Pertumbuhan LPD Desa Pakraman Kaliakah Kangin 2016 s/d 2018

\begin{tabular}{|l|c|c|c|c|}
\hline & 2016 & 2017 & 2018 & $\begin{array}{c}\text { Pertumbuhan } \\
(\%)\end{array}$ \\
\hline Aset & 645,089 & 484,592 & 371,739 & -24.08 \\
\hline Simpanan & 345,213 & 249,985 & 150,723 & -33.64 \\
\hline Kredit & 569,646 & 464,353 & 376,973 & -18.65 \\
\hline Pendapatan & 229,492 & 170,460 & 121,263 & -27.29 \\
\hline Biaya & 198,767 & 155,216 & 110,090 & -25.49 \\
\hline Laba & 30,724 & 15,244 & 11,090 & -38.81 \\
\hline
\end{tabular}

e. Dalam penelitian ini ditemukan bahwa kredit bermasalah/non performing loan pada LPD Desa Pakraman Kaliakah Kangin ini mengalami peningkatan dalam 3 (tiga) tahun terakhir yaitu 9,3\% pada $2016,15,7 \%$ pada 2017 dan $25,8 \%$ pada 2018 - Peningkatan ini dapat disebabkan oleh melemahnya dari usaha debitur yang mengakibatkan terganggunya pengembalian kredit dan sebagian besar adalah partisipasi atau kesadaran untuk mengembalikan pinjaman tepat waktu karena belum terdapat peraturan atau perarem yang mengikat.

Dalam buku Standar Kerja Organisasi dan Manajemen SDM LPD Bali pada Bab III mengenai Penataan Organisasi bagian Kesatu (legalitas) dinyatakan dalam pasal 5 yang berbunyi:

1 Keberadaan LPD harus dilindungi berdasarkan hukum adat di masing masing desa pakraman

2 Bentuk hukum adat sebagaimana dimaksud pada ayat (1) meliputi antara lain: awig-awig desa pakraman, perarem desa pakraman tentang LPD dan keputusan paruman desa pakraman

3 Hukum desa pakraman tentang LPD, harus berpedoman kepada peraturan Daerah Propinsi bali tentang LPD, Peraturan Gubernur tentang LPD dan Peraturan perundangan-undangan yang berlaku.

Berdasarkan pada penelitian yang dilakukan peneiti di LPD Desa Pakraman Kalikah kangin dinyatakan bahwa saat ini perarem Pesa pakraman tentang LPD 
masih dalam proses pembuatan. Sehingga hal ini dapat menimbulkan ternyadinya permasalahan antara LPD dan krama belum dapat diselesaikan.

\section{Faktor Eksternal LPD Desa Pakraman Kaliakah Kangin}

Faktor ekternal dalam sebuat perusahaan terdiri atas peluang dan ancaman. Melalui penelitian yang dilakukan di LPD Desa Pakraman Kaliakah Kangin baik secara wawancara mendalam maupun observasi didapatkan peluang dari LPD Desa

Pakraman Kaliakah Kangin adalah sebagai berikut

a. Peluang adalah berbagai hal dan situasi yang menguntungkan bagi suatu perusahaan, serta kecenderungan-kecenderungan yang merupakan salah satu sumber peluang (Freddy Rangkuti, 2013). Pangsa pasar untuk LPD Desa Pakraman Kaliakah Kangin saat ini masih terbuka. Ini dapat dilihat banyakya lembaga keuangan lain yang mampu masuk di wilayah desa pakraman kaliakah kangin ini. Dilihat dari potensi wilayah Desa Pakraman Kaliakah Kangin cukup luas yang sebagian besar adalah pertanian dan perkebunan serta perdagangan. Hasil dari pertanian dan perkebunan serta perdagangan ini diharapkan dapat dikelola oleh LPD, sehingga dapat kembali disalurkan untuk meningkatkan pertumbuhan ekonomi masyarakat kaliakah kangin.

b. Ancaman adalah faktor-faktor lingkungan yang tidak menguntungkan dalam perusahaan jika tidak diatasi maka akan menjadi hambatan bagi perusahaan yang bersangkutan baik masa sekarang maupun yang akan datang. Ancaman merupakan pengganggu utama bagi posisi perusahaan (Freddy Rangkuti, 2013). Berdasarkan penelitian ini diketahui bahwa ketatnya persaingan antar lembaga keuangan dimana masing lembaga keuangan berlomba-lomba untuk menarik nasabah dengan berbagai cara misalnya Bank umum dengan KURnya dan lembaga lain dengan menawarkan bunga kompetitif. Ditambah lagi saat ini kondisi LPD yang belum mendapatkan kepercayaan oleh krama sehingga lembaga keuangan lain dapat dengan mudah masuk dan mendominasi di wilayah Desa Pakraman Kaliakah Kangin. 
6. Analisis SWOT LPD Desa Pakraman Kaliakah Kangin

\begin{tabular}{|c|c|c|}
\hline Faktor Internal (SW) & $\begin{array}{l}\text { KEKUATAN (S) } \\
\text { • Loyalitas pegawai }\end{array}$ & $\begin{array}{l}\text { KELEMAHAN (W) } \\
\text { - } \quad \text { Citra lembaga } \\
\text { - Kepercayaan nasabah } \\
\text { - Pertumbuhan usaha } \\
\text { - Kredit bermasalah } \\
\text { - } \quad \text { Perarem (aturan) }\end{array}$ \\
\hline $\begin{array}{l}\text { PELUANG (O) } \\
\text { Prospek pembiayaan } \\
\text { masih terbuka, } \\
\text { penggalian dana masih } \\
\text { dapat ditingkatkan dilihat } \\
\text { dari potensi desa dari } \\
\text { hasil pertanian dan } \\
\text { perkebunan }\end{array}$ & $\begin{array}{l}\text { STRATEGI S-O } \\
\text { - Memaksimalkan } \\
\text { sosialisasi } \\
\text { menggunakan media } \\
\text { promosi yang lebih } \\
\text { agresif oleh pihak } \\
\text { LPD }\end{array}$ & $\begin{array}{l}\text { STRATEGI W-O } \\
\text { - Memperbaiki citra } \\
\text { lembaga agar dapat } \\
\text { mengembalikan } \\
\text { kepercayaan } \\
\text { masyarakat } \\
\text { - Memprioritaskan } \\
\text { penyelesaian kredit } \\
\text { bermasalah dan } \\
\text { sosialisasi untuk } \\
\text { penggalian dana } \\
\text { masyarakat } \\
\text { Segera } \\
\text { merampungkan } \\
\text { perarem atau } \\
\text { peraturan yang } \\
\text { kemudian di } \\
\text { sosialisasikan agar } \\
\text { menarik kembali } \\
\text { minat krama }\end{array}$ \\
\hline $\begin{array}{l}\text { ANCAMAN (T) } \\
\text { Persaingan antar sesama } \\
\text { lembaga keuangan }\end{array}$ & $\begin{array}{l}\text { STRATEGI S-T } \\
\text { - Meningkatkat } \\
\text { keunggulan bersaing } \\
\text { lembaga dengan lebih } \\
\text { banyak melakukan } \\
\text { sosialisasi }\end{array}$ & $\begin{array}{l}\text { STRATEGI W-T } \\
\text { Mengoptimalkan } \\
\text { sosialisasi dan pembinaan } \\
\text { kepada krama }\end{array}$ \\
\hline
\end{tabular}




\section{PENUTUP}

Melalui penelitian yang berkaitan dengan strategi daya saing pada lembaga perkreditan desa khususnya di LPD Desa Pakraman Lelateng, Ditemukan hasil penelitian yaitu faktor internal LPD Desa Pakraman Lelateng adalah citra perusahaan yang baik, kepercayaan nasabah, sumber daya manusia yang kompeten, pertumbuhan usaha yang baik, kredit bermasalah, pemanfaatan teknologi dan daerah operasional terbatas. Faktor eksternal LPD Desa Pakraman Lelateng yaitu peluang pembiayaan dan pengumpulan dana masih terbuka serta persaingan ketat antar sesama lembaga keuangan.

Strategi memaksimalkan kinerja LPD Desa Pakraman Lelateng dengan melayani dan memasarkan produk dengan media promosi yang lebih agresif melalui sosialisasi dan pemanfaatan teknologi serta meningkatkan keandalan sumber daya manusia melalui pelatihan. Strategi menjaga kepercayaan Krama Desa dan hubungan baik terhadap LPD sebagai motivasi untuk mengelola perekonomian desa secara mandiri sehingga baik LPD dan Krama Desa dapat saling menguntungkan. Strategi mengembangkan pasar desa dan unit-unit kelompok usaha di masing-masing Banjar untuk mengembangkan potensi perekonomian desa. Strategi meningkatkan manajemen resiko untuk menanggulangi permasalahan dengan intensif berkordinasi dengan pengawas internal. Mengembangkan produk baru pada bidang dana maupun kredit guna menghadapi persaingan.

Melalui penelitian yang berkaitan dengan strategi daya saing di lembaga keuangan khususnya di LPD Desa Pakraman Kaliakah Kangin, ditemukan hasil penelitian yaitu faktor internal LPD Desa Pakraman Kaliakah Kangin adalah; loyalitas pegawai/SDM, citra lembaga yang kurang baik, kepercayaan nasabah, kredit bermasalah, pertumbuhan usaha, perarem yang belum terselesaikan. Faktor eksternal LPD Desa Pakraman Kaliakah Kangin yaitu: peluang pembiayaan dan pengumpulan dana masih terbuka, dan persaingan ketat antar sesama lembaga keuangan. Strategi untuk mengoptimalkan kinerja LPD Desa Pakraman Kaliakah Kangin adalah dengan sosialisasi oleh Pengurus LPD bersama tokoh masyarakat kepada seluruh krama desa untuk membangun kembali kepercayaan dan partisipasi kepada LPD Desa Pakraman Kaliakah Kangin. Strategi selanjutnya yaitu memprioritaskan penyelesaian kredit bermasalah dan penggalian dana masyarakat melalui pembinaan dan sosialisasi serta dengan meningkatkan pelayanan. Strategi selanjutnya yaitu dengan segera merampungkan perarem untuk menguatkan keberadaan lembaga dan kemudian di sosialosasikan untuk menarik kepercayaan dan partisipasi masyarakat. 
Keterbatasan peneliti adalah, tidak bisa meneliti keseluruhan fenomena yang terjadi di LPD Desa Pakraman Lelateng maupun LPD Desa Pakraman Kaliakan Kangin. Oleh karena itu, diharapkan kiranya rekomendasi ini dapat memberi panduan dan kontribusi positif untuk penelitian mendatang yang berkaitan dengan lembaga keuangan lainnya yang ada hubungannya dengan penelitian ini.

Perkembangan informasi dan teknologi akan terus berkembang dari waktu ke waktu. Sejalan dengan perkembangan tersebut selalu ada dampak yang berimbas bagi para lembaga keuangan mikro khususnya LPD di Bali maupun pelaku usaha. Oleh sebab itu diharapkan penelitian selanjutnya dapat melengkapi kekurangan dan keterbatasan penelitian ini menggunakan aspek maupun metode lain sebagai acuan dalam strategi daya saing maupun pengembangan lembaga keuangan. 


\section{DAFTAR PUSTAKA}

Afifuddin. (2010). Pengantar Administrasi Pembangunan. Bandung: Alfabeta.

Arta, D.P.M., dan Devi, S. (2015). Perumusan Strategi Bisnis Dan Implikasinya Terhadap Strategi Pemasaran, Juima, 5 (2).

Assauri, S. (2016). Strategic Management Sustainable Competitive Advantages. Jakarta: PT. Rajagrafindo Persada.

Bali, I.N.A.P., and Darma, G.S. (2019). Menguji Kesiapan Pengelolaan Desa Berbasis Manajemen Modern Guna Menghadapi Era Revolusi Industri 4.0, Jurnal Manajemen \& Bisnis, 16 (2): 1-13.

Budiasni, N.W.N., and Darma, G.S. (2016). Penerapan Corporate Social Responsibility pada Lembaga Keuangan Berbasis Kearifan Lokal, Jurnal Manajemen \& Bisnis, 13 (2): 119.

Darma, G.S. (2004). Improving the Aligment of Business and Information Strategies, Jurnal Ekonomi \& Bisnis, 16 (1): 1-28.

Darma, G.S. (2012). 100 Konsultasi Praktis Strategi Bisnis. Denpasar: Undiknas Press.

Darma, G.S. (2019). Kacamata Media, Kesuksesan Bersyarat. Indonesia: Pustaka Larasan Press.

Darma, G.S., Apollo, A., Rusmanda, G., and Umar, Y. (2019). Digital Education 4.0. Indonesia: Cakra Media Utama Press.

Darma, G.S. (2018). Seuntai Pesan, Menjawab Zaman. Indonesia: Pustaka Larasan Press.

Dewi, N.K.Y.W., and Darma, G.S. (2019). Strategi Investasi \& Manajemen Resiko Rumah Sakit Swasta di Bali, Jurnal Manajemen \& Bisnis, 16 (2): 110-127.

David, F.R. (2011). Strategic Management Manajemen Strategi Konsep Edisi 12. Jakarta: Salemba Empat.

Ellitan, L. (2002). Praktik-Praktik Pengelolaan Sumber Daya Manusia dan Keunggulan Kompetitif Berkelanjutan, Jurnal Manajemen dan Kewirausahaan, 4 (2).

Giriama, K.D.S., dkk (2015). Evaluasi Sistem Pengendalian Internal Pada Pemberian Kredit di Lembaga Perkreditan Desa (LPD) Sudaji, E-Journal Uniersitas Pendidikan Ganesha, 3 (1).

Glueck, W.F., dan Jauch, L.R. (1994). Manajemen Strategis dan Kebijakan Perusahaan. Jakarta: Erlangga.

Handoko, T. H. (2011). Manajemen Edisi 2. Yogyakarta: BPFE Yogyakarta. 
Handika, M.R., Maradona, A.F., and Darma, G.S. (2018). Strategi Pemasaran Bisnis Kuliner Menggunakan Influencer Melalui Media Sosial, Jurnal Manajemen \& Bisnis, 15 (2): 188-199.

Harefa, M. (2016). Perkembangan, Tantangan, dan Perspektif Kebijakan Pengembangan Lembaga Perkreditan Desa (LPD) Bali Sebagai Intermediasi Keuangan. Jakarta: Pusat Penelitian Badan Keahlian DPR RI.

Hamidi. (2014). Metode Penelitian Kualitatif Aplikasi Praktis Pembuatan Proposal dan Laporan Penelitian. Malang: UMM Press.

Irawan, D., dkk (2013). Analisis Strategi Pengembangan Lembaga Keuangan Mikro Syariah (LKMS) Pedesaan (Studi Kasus BMT Al Hasanah Sekampung), JIIA, 1 (1).

Kanten, I.K., and Darma, G.S. (2017). Consumer Behaviour, Marketing Strategy, Customer Satisfaction, and Business Performance, Jurnal Manajemen \& Bisnis, 14 (2): 143-165. Kusnadi, D.S., and Darma, G.S. (2018). Menakar Implementasi Green Marketing Pada Usaha Kecil Menengah, Jurnal Manajemen \& Bisnis, 15 (1): 1-18.

Moleong, L.J. (2007). Metodelogi Penelitian Kualitatif Edisi Revisi. Bandung: PT. Remaja Rosdakarya.

Peraturan Gubernur Bali Nomor 44 Tahun 2017 Tantang Pelaksanaan Peraturan Daerah Provinsi Bali Nomor 3 Tahun 2017 Tentang Lembaga Perkreditan Desa

Peraturan Daerah Provinsi Bali Nomor 3 Tahun 2017 Tentang Lembaga Perkreditan Desa

Purnama, A. (2013). Pengaruh Gaya Kepeminpinandan Sistem Pengendalian Manajemen terhadap Loyalitas Karyawan di Perusahaan Keluarga PT. SUS Surabaya, Jurnal Ilmiah Universitas Surabaya, 2 (2).

Porter, M.E. (1993) Keunggulan Bersaing Menciptakan dan Mempertahankan Kinerja Unggul. Jakarta: Erlangga.

Rangkuti, F. (2013). Analisis SWOT Teknik Membedah Kasus Bisnis. Jakarta: Gramedia Pustaka Utama.

Rachmat. (2014). Manajemen Strategik. Bandung: CV Pustaka Setia.

Rusmahadewi, I.A., and Darma, G.S. (2018). Team Engagement and Performance Management (A Study of Banking Industry), Jurnal Manajemen \& Bisnis, 15 (3): 3850.

Sadiartha, A.A.N.G. (2017). Lembaga Perkreditan Desa sebagai Penopang Ke-ajegan Budaya Ekonomi Masyarakat Bali, Jurnal Kajian Bali, 7 (02). 
Setiawan, Y.N., dan Japarianto, E. (2014). Analisis Pengaruh Kepercayaan, Jaminan Rasa Aman, dan Aksebilitas Terhadap Minat Menabung Nasabah Bank Danamon di Surabaya, Jurnal Manajemen Pemasaran Petra, 2 (1).

Sudaryono. (2017). Pengantar Manajemen Teori dan Kasus. Yogyakarta: CAPS.

Sugiyono. (2017). Metode Penelitian Kualitatif. Bandung: Alfabeta.

Suryanata, I.G.N.P. (2017). Potret LPD (Lembaga Perkreditan Desa) di Bali Pendekatan Kajian Ilmiah. Denpasar: Universitas Pendidikan Nasional.

Sutojo, S., dan E. John Aldridge. (2008). Good Corporate Governance Tata Kelola Perusahaan yang Sehat. Jakarta: PT. Damar Mulia Pustaka.

Sundarianingsih, P. (2014). Evaluasi Keberhasilan Lembaga Perkreditan Desa (LPD) dalam Menggerakan Sosial Ekonomi Masyarakat Pedesaan, Jurnal Ekonomi Pembangunan, $12(1)$.

Standar Kerja Organisasi dan Manajemen SDM LPD Bali Tahun 2015.

Wahyuni, N.W., dkk. (2017). Analisis Modal Sosial Dalam Berdirinya Kembali Lembaga Perkreditan Desa (LPD) Desa Pakraman Tusan Kecamatan Banjarangkan Kabupaten Klungkung, Jurnal Akuntansi Universitas Pendidikan Ganesha, 8 (2).

Wiagustini, N.LP., dkk. (2014). Model Pemberdayaan Lembaga Perkreditan Desa (LPD) Sebagai Sumber Pendanaan Usaha Mikro Kecil Menengah (UMKM) Di Kabupaten Gianyar, Jurnal Manajemen Strategi Bisnis dan Kewirausahaan, 8 (1).

Wibawa, I.B.P., and Darma, G.S. (2017). Administrasi Pajak Daerah Melalui Penerapan Aplikasi SIMPAD NG dalam Perspektif Good Governance di Kabupaten Buleleng, Jurnal Ilmiah Administrator: Menelaah Masalah Kebijakan Publik dan Pembangunan, 9 (1): 68-78.

Widiari, I.A.R., and Darma, G.S. (2017). Evaluasi Kinerja Pegawai Kontrak Melalui Tujuh Kompetensi Spencer Pada Pelayanan Denpasar Sewerage Development Project (DSDP), Jurnal Ilmiah Manajemen \& Bisnis, 2 (2): 360-367.

Wheelen, T.L., Hunger, J.D. (2010). Strategic Management and Business Policy Achieving Sustainability. Twelfth Edition. Pearson. 